\section{Recovering Bacon's paradox}

SIR - As a palaeontologist, I try to be especially sensitive to one great feature of human intellectual struggle: the incessant rediscovery of former and forgotten wisdom. Plus ça change, plus c'est la même chose. Zakaria Erzinclioglu is sorely distressed (Nature 355, 195; 1992) that we label fossils from the Earth's youth as ancient: "One of the most absurd and persistent misuses of words in science is the use of the word 'ancient' to describe species that flourished millions of years ago .... The animals themselves are not ancient in any sense at all. They died out a long time ago, when the Earth was young." Ralph Estling then replies (Nature 355, 667; 1992): "Trilobites and Aristotle are both; they were here early (earlier than we were), younger than we are, but from our habitual standpoint of looking back through time from where we happen to be at the moment, they are ancient and therefore older than we."

I do not dispute Estling's pluralistic resolution, but wish to point out that these current antagonists are replaying one of our oldest linguistic disputes, indeed a classic paradox of our literary traditions. Francis Bacon gave a first crisp statement in his Advancement of Learning in 1605 (though R. K. Merton, in his charming book, On the Shoulders of Giants, traces earlier uses to Giordano Bruno and even to the apocryphal book II Esdras of the Vulgate). Bacon wrote: Antiquitas saeculi, juventus mundi (or, roughly, "the good old days were the world's youth") He later expanded in aphorism LXXXIV of the Novum Organum: "the old age of the world ... is the attribute of our own times, not of that earlier age in which the ancients lived; and which, though in respect of us it was the elder, yet in respect of the world it was the younger." This observation was generally called "the Baconian paradox" when seventeenth century scholars so fiercely debated the relative merit of classical versus modern wisdom - a vital controversy surrounding the origin of modern science in Newton's age.

Jonathan Swift provided the most famous expression of Bacon's paradox in his wonderful satire on this great debate, The Battle of the Books (1704). One Friday night, in St James's Library, the books of Plato and Aristotle square off against those of Newton and Descartes:

Discord grew extremely high ... Here a solitary ancient, squeezed up among a whole shelf of moderns, offered fairly to dispute the case, and to prove by manifest reason, that the priority was due to them But these [moderns] denied the premises, and seemed very much to wonder, how the ancients could pretend to insist upon their antiquity, when it was so plain . . . that the moderns were much the more ancient of the two.

Bacon's paradox has since experienced cycles of oblivion and rediscovery. Jeremy Bentham, for example, left this aphorism among his unfinished papers (published posthumously in 1824): "What is the wisdom of the times called old? Is it the wisdom of gray hairs? No. - It is the wisdom of the cradle."

This antiquarian epitome would be worthless pedantry if the subject of Bacon's paradox did not raise two central questions for modern thought and the history of science. First, the issue does not arise until historicism and the notion of progress enter Western traditions - and these seminal ideas represent one of the great contributions of emerging science and technology. Why worry about whether the past was old or young if time runs in the repetitive cycles of Plato's Great Year and does not either advance or regress? The paradox has meaning only in the world constructed by science; indeed, Swift refers to Bacon's aphorism as "the modern paradox". Bacon emphasizes the same point in his obvious simile of time's passage with accumulation of knowledge in human ageing - his defence of the 'moderns' in the battle of the books: "And truly as we look for greater knowledge of human things and a riper judgement in the old man than in the young so in like manner from our age ... much more might fairly be expected than from the ancient times, inasmuch as it is a more advanced age of the world."

Second, Bacon's observation is a true paradox — a seemingly selfcontradictory or absurd statement that happens to be true. As with other classical paradoxes, we both wince and revel in Bacon's idea because it embodies one of the inherent ambiguities of our complex lives, logics and phenomenologies. Pace Erzinclioglu, there is no solution; both perspectives, from both ends, are correct - and they do contradict one another. Rossini turned both 48 and 200 years old on 29 February 1992 (1800 and 1900 were not leap years in our Gregorian calendar). Frederick, the pirate apprentice, subject to the very same ambiguity (and faced with the prospect of bondage till the age of 88 , his majority by true birthdays) touches the heart of our human predicament in W. S. Gilbert's sprightly words:

How quaint the ways of paradox! At common sense she gaily mocks! STEPHEN JAY GOULD

Museum of Comparative Zoology, Harvard University, Cambridge, Massachusetts 02138, USA
Babbage's dates

SIR - Heilbron and Bynum ${ }^{1}$ mistakenly state that 1992 marks the bicentenary of the birth of Charles Babbage. In fact, Babbage was born on 26 December 1791 , so that the chance for anniversary celebrations passed a week before publication of Heilbron and Bynum's article.

The confusion lies with Charles Babbage himself, who believed to the end of his life that he was precisely a year younger than he was. This was not known until rather more recently ${ }^{2}$.

D. I. STEEL

Anglo-Australian Observatory, Coonabarabran, NSW 2357.

Australia

1. Helbron, J. L. \& Bynum, W. F. Nature 355, 11-14 (1992).

2. Hyman, A. Charles Babbage: Pioneer of the Computer (Oxford University Press, 1982).

\section{Insensitive ads}

SIR - For several months, scientific journals have been publishing an advertisement for the Invitrogen company entitled "Native Expression" (for example Nature 23 January 1992, facing page 294). Although editorial staff are not responsible for the contents of advertisements, such an advertisement is insensitive, particularly at a time when the extermination of primitive people is a major concern. Taking DNA samples from them is good. To care about their horrible fate is much more important. Elementary human decency should forbid such a bad and vulgar demonstration of a poor and misplaced sense of humour.

This advertisement shows where the increasing desire to attract attention at any price can lead us.

Facultes Universitaires

$N-D$ de la Paix,

Departement de Physiologie

Humaine,

B-5000 Namur

Belgium

\section{Defining science}

SIR - "Is molecular biology yet a science?" (Nature 355, 201; 1992) reminded me of a quotation from Lord Kelvin:

When you can measure what you are speaking about, and express it in numbers, you know something about it; but when you cannot measure it, when you cannot express it in numbers, your knowledge is of a meagre and unsatisfactory kind: it may be the beginning of knowledge, but you have scarcely, in your thoughts, advanced to the stage of science.

JANARDAN D. KHANDEKAR

Division of Medical Oncology,

Evanston Hospital,

2650 Ridge Avenue,

Evanston, Illinois 60201, USA 